DOI https://doi.org/10.30525/978-9934-588-80-8-2.56

\title{
FORMATION OF FOREIGN LANGUAGE COMPETENCE OF FUTURE TEACHERS BY MEANS OF MEDIA TECHNOLOGIES
}

\author{
Lipatov V. M. \\ Senior Lecturer at the Department of English Philology \\ Drahomanov National Pedagogical University \\ Kyiv, Ukraine
}

Integration of the Ukrainian state to European and world community raises the issue of active usage of foreign languages in all spheres of public life, which requires raising the level communicative competence of foreign language teachers taking into account radical changes in information technology support of training specialists. The role and importance of a thorough study of foreign languages are evidenced by European and domestic documents on education: the recommendations of the Council of Europe «From the linguistic Diversity to Multilingual Education: A Guide to Language Policy Development in Europe»(2007); the decision of the Barcelona summit to introduce the formula «Native language plus two foreign languages»(2000); Berlin Declaration of Higher Quality education (2003); The concept of language education in Ukraine (2010); «National White Paper Education of Ukraine»(2009); Laws of Ukraine «On Higher Education» (2014) and «On Education»(2017) and others.

To prepare a student of pedagogical specialty for foreign language communication in the information society, it is advisable to integrate the content of media education in the educational process of learning a foreign language, because media education is declared by UNESCO as one of the priorities in pedagogy of the XXI century. According to the researcher $\mathrm{O}$. Fedorov, media education is the process of personal development with the help and on the material of mass media (media) in order to form a culture of communication with the media, creative, communicative abilities, critical thinking, skills of perception, interpretation, analysis and evaluation of media texts. learning different forms of self-expression with the help of media technology [7, p. 27]. The result of media education is the formation of media literacy of the individual, namely his ability to analyze and synthesize media texts [7, p. 25]. Specific techniques and forms of work with mass communication sources in the process of learning a foreign language make it possible to achieve both educational and methodological and cognitive results [5, p. 25]. The result of learning a foreign language is 
the formation of foreign language communicative competence, which is achieved through content, methods, forms, teaching aids and more. The purpose of foreign language communicative competence is not the accumulation of knowledge, but the ability to use them in foreign language activities [5, p. 13].

Foreign language training as a component of professional training of future school teachers takes place in an era of rapid development of media information society. This greatly affects on the organization of the learning process. The integration of media education into the disciplines of the foreign language cycle contributes to the formation of basic competencies of the modern personality, namely: information media, digital and foreign language communicative ones.

Analysis of research has shown that aspects of media integration technologies in academic disciplines substantiated by O. Bondarenko, A. Lytvyn, V. Robak, F. Rogou, N. Chicherina, S. Shaibe, L. Zaznobina and others domestic and foreign researchers. Scientists claim [1;3] that by integrating media education into academic disciplines, the teacher achieves the goal formation of foreign language competence and raises the level of studying the specific subject. Media education in higher education involves the training of not only specialists for the media, media educators and media psychologists. Media educational elements are included in the educational ones programs of the cycle of professionally-oriented training in other specialties in the corresponding volumes. At the same time, students of different fields of study gain knowledge about the media, develop their own media competence, which, in particular, gives them special grounds to consider media education itself as media technology. Ukraine has several successful examples of developing high school media didactics and the use of media texts in education process. I In the English-speaking world, media education began to develop actively with the middle of the last century. To the Ukrainian educational space the concept of «medi», as well as the terms of which it is part, came much later. Today, many of them are «umbrella» concepts (media didactics, media psychology, blog didactics, etc.), which initiates a new terminology [5].

Training of future school teachers we are guided by the classification of the scientist I. Sakhnevych, namely: pressure technologies, film technologies, computer technologies, multimedia technologies, network technologies technologies, telecommunication technologies [4]. These media technologies make a great contribution to the realization of learning goals of foreign languages and media education. They successfully integrate with other modern learning technologies, such as Project learning, Inverted classroom (Flipped Classroom), Mobile Learning, etc. Visual (images, 212 
photos, comics, emoji, timelines, etc.), Audio (audio recordings, podcasts, etc.); Audio-Visual (movies, cartoons, interactive video) and etc..

The development of education today is organically linked with increasing the level of its information potential. This characteristic largely determines both the direction of the evolution of education itself and the future of the whole society. For the most successful orientation in the world information space it is necessary for students to master information as well as computer and information culture, as the priority in the search for information more and more is provided to the Internet. For example, the Internet provides the ability to search quickly for information that is useful in terms of educational activities, her analysis and evaluation. Students complete tasks on the Internet principles, classifications, definitions, models, images, rules, etc. Multimedia software tools allow them to integrate text, graphics, animation, video and audio information. Simultaneous use of several channels of educational perception information allows to increase the level of learning material [4].

Thus, foreign language training of future school teachers needs to be updated by introducing topics on media and expanding the methodological workshop with media and related media technologies, which will help increase level of foreign language communicative competence, the formation of skills in working with information, networking, creating their own media products, etc. Today's society needs creative, enterprising professionals capable of professional self-improvement and personal self-development. In modern conditions information space, the problem of a high level of professionalism is relevant. Therefore, we consider that it is necessary to improve the quality of foreign language training of future professionals through the use of media of various types.

\section{References:}

1. Its S.V. Pedagogical conditions of formation of professional competence future teacher of a foreign language by means of media education: author's ref. dis. On obtaining sciences. degree. Cand. ped. Science: special. 13.00.04 «Theory and methods professional education «/ S.V. Its. Zhytomyr, 2014. 20 p.

2. Lytvyn AV, Robak VE Tasks of media education in vocational training /A.V. Lytvyn, V.E. Robak // Theoretical and methodological principles of organization media education. Proceedings. Series: Pedagogy. 2013. № 3. P. 31-37

3. Media education and media literacy: a textbook [ed.-emphasis. VF Ivanov, OV Volosheniuk; Edited by VV Rizun]. K .: Free Press Center, 2013. 352 p. 
4. Morse N., O. Glazunova, «Models of effective use of information and communication and distance learning technologies in the higher educational institution «Information technologies and teaching aids, 2008, № 6 (2), [Electronic resource]. Access mode: scholar.google.com.ua/citations?user= BujWYRcAAAAJ\&hl=en

5. Onkovich GV Media didactics of higher school: Ukrainian experience / G.V. Onkovych // Higher education of Ukraine. 2013. № 1. P. 23-29.

6. Sakhnevych I.A Pedagogical conditions of application of media educational technologies in professional training of future oil and gas specialists: author's ref. dis. for science. degree. Cand. ped. Science: special. 13.00.04 «Theory and methods of professional education «/ IA Sakhnevych. Kyiv. 2012. 20 p.

7. Fedorov A.V. Dictionary of terms on media education, media pedagogy, media literacy, media competence. / AV Fedorov. M .: MOO «Information for All», 2014. 64 p.

DOI https://doi.org/10.30525/978-9934-588-80-8-2.57

\title{
ДОСВІД ВИКОРИСТАННЯ ЗАСОБІВ МАСОВОЇ КОМУНІКАЦЇ̈ У ВСТУПНІЙ КАМПАНІЇ ВІЙСЬКОВОГО ІНСТИТУТУ
}

\author{
Міхсев Ю. I. \\ кандидат технічних наук, \\ заступник начальника науково-дослідного відділу інформачійної \\ та кібернетичної безпеки наукового центру \\ Житомирський військовий інститут імені С. П. Корольова \\ Носова Г. Д. \\ старший науковий співробітник науково-дослідного відділу \\ інформаційної та кібернетичної безпеки наукового иентру \\ Житомирський військовий інститут імені С. П. Корольова

\section{Наумчак О. М.} \\ ад’юнкт науково-організаційного відділення \\ Житомирський військовий інститут імені С. П. Корольова \\ м. Житомир, Украӥна
}

Всесвітня пандемія COVID-19 суттєво вплинула на загальний підхід до розгортання вступної кампанії усіх закладів вищої освіти (ЗВО) 